\title{
ANGKA KEJADIAN STOMATITIS APTHOSA REKUREN (SAR) DITINJAU DARI FAKTOR ETIOLOGI DI RSGMP FK UNSRAT TAHUN 2014
}

\author{
${ }^{1}$ I Made A. Yogasedana \\ ${ }^{2} \mathrm{Ni}$ Wayan Mariati \\ ${ }^{2}$ Michael A.Leman
}

\author{
${ }^{1}$ Kandidat Skripsi ProgramStudi Pendidikan Dokter Gigi Fakultas Kedokteran \\ ${ }^{2}$ Program Studi Pendidikan Dokter Gigi Fakultas Kedokteran \\ Universitas Sam Ratulangi Manado \\ E-mail: yogasedanaace@gmail.com
}

\begin{abstract}
Stomatitis is an inflammattory process of the mucous lining of any structure in the oral cavity, such as the cheeks, gums (gingivitis), tongue (glossitis), lips, and the roof or floor of the cavity. Inflammation can be caused by several conditions in the mouth (such as poor oral hygiene, poor tooth arrangement), mouth injuries due to hot food or drink, or by conditions that affect the whole body (such as medications, allergic reactions, or infections). This study aimed to obtain the prevalence of patients suffering from recurrent stomatitis apthosa in RSGMP FK UNSRAT in 2014. This was a retrospective descriptive study. There were 69 samples categorized according to gender, age, type of treatment, and etiology of the disease. The results showed that stomatitis recurrent apthosa was most common in women with predisposing factors, as follows: trauma (53\%), stress $(21.7 \%)$, hormonal imbalance (17.3\%), genetic (11.5\%), and allergy $(1.1 \%)$.
\end{abstract}

Keywords: stomatitis recurrent apthosa, etiology

\begin{abstract}
Abstrak: Stomatitis adalah inflamasi lapisan mukosa dari struktur apa pun pada mulut; seperti pipi, gusi (gingivitis), lidah (glositis) bibir, dan atap atau dasar mulut. Kata stomatitis sendiri berarti inflamasi pada mulut. Inflamasi dapat disebabkan oleh kondisi mulut itu sendiri (seperti oral higiene yang buruk, susunan gigi yang buruk), cedera mulut akibat makanan atau minuman panas, atau oleh kondisi yang memengaruhi seluruh tubuh (seperti obat-obatan, reaksialergi, atau infeksi). Penelitian ini bertujuan untuk mengetahui prevalensi pasien yang menderita stomatitis apthosa rekuren yang ditangani di RSGMP FK UNSRAT pada tahun 2014. Jenis penelitian ini deskriptif retrospektif. Terdapat 69 sampel yang dikategorikan sesuai jenis kelamin, usia, jenis perawatan dan etiologi penyakit. Hasil penelitian menunjukkan kejadian stomatitis apthous rekuren terdistribusi sebagai berikut: paling banyak terjadi pada perempuan dengan faktor predisposisi: trauma (53\%), stres (21,7\%), ketidakseimbangan hormonal (17,3\%), genetik (11,5\%), alergi $(1,1 \%)$.
\end{abstract}

Kata kunci: stomatitis apthosa rekuren, etiologi

Banyak orang yang kurang memelihara atau mempedulikan penampilan serta kebersihan mulut mereka karena kesibukan dan rutinitas sehari-hari. Hal ini dapat berpengaruh menurunkan daya tahan tubuh serta terjadinya Sariawan. Sariawan secara medis dapat didefinisikan inflamasi lapisan mukosa dari struktur pada mulut; seperti pipi, gusi (gingivitis), lidah (glositis) bibir, dan atap atau dasar mulut dengan kata lain 
Stomatitis. Stomatitis sendiri berarti inflamasi pada mulut. Inflamasi ini dapat disebabkan oleh kondisi mulut itu sendiri (seperti susunan gigi yang buruk), cedera mulut akibat makanan atau minuman panas, atau oleh kondisi yang memengaruhi seluruh tubuh (seperti obat-obatan, reaksi alergi, atau infeksi). ${ }^{1,2}$

Seorang pasien dengan keluhan penyakit ini merasa nyeri yang sangat dalam dan kadang-kadang merasa terbakar. Stomatitis juga didefinisikan sebagai inflamasi lapisan struktur jaringan lunak pada mulut dengan tanda kemerahan, pembengkakan, dan kadang-kadang perdarahan dari daerah yang terkena. Bau mulut (halitosis) juga mungkin menyertai keadaan ini. Stomatitis terjadi pada semua kelompok umur, dari bayi hingga dewasa tua. $^{2}$

Stomatitis Apthosa Rekuren (SAR) adalah jenis yang lebih spesifik dari stomatitis, muncul dengan ulkus yang dangkal dan nyeri yang biasanya ada di bibir, pipi, gusi, atap atau dasar mulut. Rentang diameter ulkus ini dari bintik kecil hingga 1 inchi $(2,5 \mathrm{~cm})$ atau lebih. ${ }^{1}$ Walaupun penyebab SAR tidak diketahui, yang diduga adalah defisiensi nutrisi, khususnya vitamin B12, folat, atau besi. Stomatitis generalisata atau stomatitis kontak dapat terjadi akibat penggunaan berlebihan dari alkohol, merica, makanan panas, atau produk tembakau. Sensitivitas terhadap obat kumur, pasta gigi, dan lipstik, dapat mengiritasi lapisan mulut. Paparan terhadap logam berat, seperti merkuri, timah, bismut, dapat menyebabkan stomatitis. $^{2}$

Mahasiswa program studi pendidikan dokter Gigi Universitas Sam Ratulangi dapat dikatakan memiliki tingkat pemahaman yang lebih yang baik karena lebih banyak mendapatkan pengetahuan tentang ilmu-ilmu kedokteran gigi dan dianggap sudah mampu untuk menangani kasus SAR. ${ }^{3}$

\section{BAHAN DAN METODE PENELITIAN}

Jenis penelitian ini deskriptif retrospektif yang bertujuan untuk menggambarkan mengenai angka kejadian SAR ditinjau dari faktor etiologi di RSGMP FK Unsrat Tahun 2014. Penelitian ini menggunakan rekam medik RSGMP FK Unsrat tahun 2014. Populasi penelitian ialah seluruh rekam medik umum tentang SAR di RSGMP FK UNSRAT. Jumlah sampel dalam penelitian ini sama dengan jumlah seluruh populasi (total sampling) dan dikategorikan berdasarkan karakteristik umur, jenis kelamin, pekerjaan, dan faktor etiologi.

Variabel penelitian ialah SAR, biasanya berupa ulser putih kekuningan tunggal maupun lebih dari satu dan faktor etiologi terdiri dari pasta gigi dan obat kumur Sodium Lauryl Sulphate (SLS), trauma, genetik, gangguan immunologi, alergi dan sensitifitas, stres, merokok, infeksi bakteri, penyakit sistemik, dan obat-obatan.

\section{HASIL PENELITIAN}

Karakteritik subjek penelitian dikategorikan berdasarkan jenis kelamin, menunjukkan subjek penelitian berjumlah 69 orang yang terdiri dari 39 orang (56\%) berjenis kelamin perempuan dan 30 orang (44\%) berjenis kelamin laki-laki. Karakteristik menurut usia, menunjukkan bahwa 20 sampel (29\%) berusia $\leq 20$ tahun, 32 sampel (46.4\%) berusia antara 21-30 tahun, 6 sampel $(8,6 \%)$ berusia antara 3140 tahun, 7 sampel (10\%) berusia antara 41-50 tahun, 4 sampel (6\%) berusia antara 51-60 tahun, dan tidak ditemukan sampel berusia $\geq 60$ tahun. Ini menunjukan penyakit Stomatitis jarang terjadi pada usia diatas 60.

Dari 69 sampel, seluruhnya mengalami lesi yang diduga SAR. Dari penelitian ini didapatkan hasil angka kejadian lesi yang diduga sebagai SAR pada RSGMP FK UNSRAT sebesar $100 \%$. 
Jurnal e-GiGi (eG), Volume 3, Nomor 2, Juli-Desember 2015

Tabel 1. Berdasarkan jenis perawatan dan jenis kelamin

\begin{tabular}{ccccccc}
\hline \multirow{2}{*}{ Jenis Perawatan } & \multicolumn{2}{c}{ Perempuan } & \multicolumn{2}{c}{ Laki-laki } & \multicolumn{2}{c}{ Total } \\
& $\mathrm{n}$ & $\%$ & $\mathrm{n}$ & $\%$ & $\mathrm{n}$ & $\%$ \\
\hline Aplikasi Kenalog & 20 & 51,3 & 21 & 70 & 41 & 59.4 \\
Dental Health Education & 18 & 46,1 & 9 & 30 & 27 & 39,2 \\
Obat-obat lain & 1 & 2,56 & 0 & 0 & 1 & 1,4 \\
Total & 39 & 100 & 30 & 100 & 69 & 100 \\
\hline
\end{tabular}

Tabel 2. Faktor Etiologi Lesi yang diduga sebagai SAR

\begin{tabular}{ccccccc}
\hline \multirow{2}{*}{ Faktor Etiologi } & \multicolumn{2}{c}{ SAR } & \multicolumn{3}{c}{ Tak ada } \\
& & keluhan SAR & \multicolumn{2}{c}{ Total } \\
\cline { 2 - 7 } & $\mathrm{n}$ & $\%$ & $\mathrm{n}$ & $\%$ & $\mathrm{n}$ & $\%$ \\
\hline Trauma & 37 & 53,3 & 32 & 46,7 & 69 & 100 \\
Keseimbangan & 12 & 17,3 & 39 & 56,5 & 69 & 100 \\
Hormonal & 8 & 11,5 & 34 & 49,2 & 69 & 100 \\
Genetik & 15 & 21,7 & 30 & 43,4 & 69 & 100 \\
Stress & 1 & 2,2 & 68 & 97,8 & 69 & 100 \\
Alergi & & & & & & \\
\hline
\end{tabular}

\section{BAHASAN}

Hasil penelitian ini mendukung teori yang mengatakan bahwa angka prevalensi SAR sekitar 5 sampai $66 \%$ dari populasi penduduk dunia dengan rata-rata $20 \%{ }^{2}$ Kelebihan 44\% dari kisaran tertinggi prevalensi populasipenduduk dunia dapat terjadi karena berbagai faktor. Hal ini juga ditegaskan dengan Literatur yang mengatakan bahwa prevalensi SAR tergantung pada daerah yang diteliti. ${ }^{2} \mathrm{Hal}$ tersebut menjadi salah satu faktoryang menyebabkan adanya kelebihanpersentase pada angka kejadian dari hasilpenelitian ini dibandingkan dengan kisaran prevalensi populasi penduduk dunia. Sampel yang pernah mengalami lesiyang diduga sebagai SAR lebih banyak daripada yang tidak pernah mengalami lesiyang diduga sebagai SAR. Hasil penelitian tersebut membuktikan teori yang menyebutkan bahwa SAR merupakan penyakit mulut yang paling banyak dialami oleh populasi manusia dan sering ditemukan oleh klinisi. Sampai saat ini SAR masih merupakan penyakit mulut yang paling sering dialami oleh manusia sepanjang hidupnya.
Jumlah sampel laki-laki dan perempuan tidak sama besar, namun berdasarkan penghitungan persentase dari jumlah sampel rekam medik yang diambil menerangkan bahwa sebanyak 39 sampel perempuan yang terlibat dalam penelitian ini, seluruhnya mengalami lesi yang diduga sebagai SAR, sehingga persentase pada sampel perempuan dalam penelitian ini sebesar $56 \%$ dan $44 \%$ sampel laki-laki yang terlibat dalam penelitian ini, keseluruhannya menderita penyakit SAR dan memeriksakan penyakit ini ke RSGMP FK Unsrat.

Seperti yang telah di dapatkan hasil yg persentase kejadian SAR lebih banyak dialami perempuan dengan persentase sebesar 56\%. Dapat dilihat bahwa dalam penelitian ini, angka kejadian lesi yang diduga sebagai SAR lebih tinggi dialami oleh perempuan dari pada laki-laki. Dari hasil di atas maka penelitian ini mendukung literatur-literatur dan penelitian dari Jonas dan Mason yang menyatakan bahwa SAR lebih sering dialami oleh perempuan dibandingkan laki-laki. 4,5,6 Tingginya angka kejadian SAR pada perempuan sering dihubungkan dengan 
faktor etiologi ketidakseimbangan hormonal yang lebih sering dialami oleh wanita pada siklus menstruasinya. Pada penelitian ini terdapat 12 sampel yang mengalami SAR pada siklus menstruasinya. Jumlah tersebut hanya 17,3\% dari jumlah sampel perempuan yang pernah mengalami SAR. Hal inilah yang bisa menyebabkan SAR lebih banyak dialami oleh sampel perempuan dalam penelitian ini. Faktor etiologi stres yang merupakan faktor etiologi tertinggi kedua dalam penelitian ini dialami oleh sebagaian besar sampel baik perempuan sehingga dapat menyebabkan tingginya angka kejadian lesi yang diduga sebagai SAR pada sampel perempuan.

Berdasarkan usia, sampel dengan usia antara 21-30 tahun paling banyak pernah mengalami lesi yang diduga sebagai SAR, yaitu sebanyak 32 sampel (46,4\%) dari dari keseluhan sampel yang terlibat dalam penelitian. Sampel yang paling sedikit pernah mengalami lesi yang diduga sebagai SAR yaitu sampel yang berusia 50-60 tahun. Dari 69 sampel berusia $<20$ tahun yang terlibat dalam penelitian ini, hanya 4 sampel (6\%) yang pernah mengalami lesi yang diduga sebagai SAR. Hasil penelitian ini sesuai dengan literatur yang menyatakan bahwa munculnya ulser SAR akan meningkat seiring dengan pertambahan usia selama dekade ketiga kehidupan (21 sampai 30 tahun). ${ }^{5}$

Penelitian ini menunjukkan bahwa faktor etiologi dari SAR yang dialami oleh sampel bukan hanya satu faktor saja, tapi juga oleh beberapa faktor etiologi yang memicu terjadinya lesi yang diduga sebagai SAR yang dialami sampel selama hidupnya. Dalam penelitian ini, faktor etiologi trauma merupakan faktor etiologi yang paling banyak mengakibatkan lesi yang diduga sebagai SAR yang dialami oleh sampel.

Dari 69 sampel, sebanyak 37 sampel (53,3\%) mengaku bahwa lesi yang diduga sebagai SAR yang dialami pada rongga mulutnya muncul setelah mengalami trauma dalam rongga mulut. Trauma yang sering dialami yaitu trauma karena terbentur sikat gigi saat menyikat gigi dan tidak sengaja tergigit bagian tertentu dari mukosa mulut. ${ }^{4}$

Hasil penelitian ini sesuai dengan literatur yang menyatakan bahwa sering dilaporkan munculnya SAR pada daerah yang mengalami trauma karena tergigit dan terbentur sikat gigi. ${ }^{4,8} 20$ orang (29\%) sampel dalam penelitian ini yang menggunakan alat ortodontik (kawat gigi) jarang mengalami lesi yang diduga sebagai SAR namun lebih sering mengalami ulser traumatik, seperti yang dinyatakan dalam literatur bahwa pengguna alat ortodontik (kawat gigi) dapat mengalami ulser traumatik akibat alat yang digunakan. ${ }^{8}$

Tingginya angka kejadian lesi SAR ini berdasarkan faktor etiologi trauma disebabkan karena gejala gejala awal seperti tergigit dan terbentur yang seolaholah menusuk mukosa mulut dan langsung disertai oleh munculnya ulser pada daerah yang trauma. Proses menjadi ulser yang berlangsung cepat dari trauma menjadi lesi yang diduga sebagai SAR yang membuat sampel menduga bahwa faktor etiologi trauma yang mengakibatkan munculnya lesi SAR yang dialaminya. Diasumsikan juga bahwa setiap terjadi trauma maka akan menimbulkan luka. Hal ini memperkuat lagi anggapan bahwa faktor etiologi trauma yang menyebabkan SAR yang dialami oleh pasien tersebut. ${ }^{9}$ Rongga mulut merupakan cermin yang baik untuk merefleksikan keadaan sistemik seseorang. Keadaan sistemik yang tidak normal dapat tercermin pada rongga mulut dengan manifestasi berbagai lesi yang dapat muncul pada rongga mulut. Kadar hormon didalam tubuh yang tidak seimbang atau mengalami fluktuasi merupakan salah satu kondisi sistemik yang dapat tercermin dalam rongga mulut. Lesi yang bermanifestasi dalam rongga mulut saat kadar hormon dalam tubuh tidak seimbang 
yaitu SAR. Hormon-hormon yang tidak seimbang yang dimaksud dalam penelitian ini yaitu hormon estrogen dan progesteron. ${ }^{7}$

Ketidakseimbangan hormonal yang juga diduga menjadi faktor etiologi lesi yang diduga sebagai SAR dialami oleh 9 sampel perempuan. Faktor etiologi ketidakseimbangan hormonal yang dimaksud dalam penelitian ini yaitu perubahan hormon progesteron dan estrogen saat siklus menstruasi. Itulah alasan mengapa faktor etiologi ketidakseimbangan hormonal hanya diteliti pada sampel perempuan. ${ }^{7}$ Dari 39 sampel perempuan yang pernah mengalami lesi yang diduga sebagaiSAR, terdapat 12 sampel yang mengalami lesi yang diduga sebagai SAR dipicu olehfaktor etiologi ketidakseimbanganhormonal. Itu berarti sebanyak 17,3\% sampel perempuan yang pernah mengalami lesi yang diduga sebagai SAR, mengalami lesi ini dipicu oleh faktor ketidakseimbangan hormonal pada siklus menstruasinya. Hal ini hampir sama dengan hasil penelitian dari Balan dkk, yang menyebutkan bahwa pada saat siklus menstruasinya, $30 \%$ perempuan mengeluhkan mengalami SAR di rongga mulutnya. ${ }^{7}$ Pada beberapa perempuan, tanda akan datangnya siklus bulanannya dapat diprediksi juga dengan munculnya SAR pada rongga mulutnya. Beberapa perempuan yang mengalami hal tersebut, mukosa mulutnya selalu muncul ulser SAR setiap bulan. ${ }^{7}$

Adanya pengaruh hormon progesteron yang memicu SAR ditunjukkan pada penelitian dari Sumintarti dan Erni Marlina yang menyebutkan bahwa pasien SAR memiliki kadar progesteron dibawah normal. Penelitian dari Jones dan Mason telah melaporkan hubungan antara SAR d engan siklus menstruasi. ${ }^{6}$

Sebanyak 8 sampel (11,5\%) mengakui bahwa lesi yang diduga sebagai SAR yang dialaminya juga dialami oleh anggota keluarga (orang tua dan saudara) dan lesi yang diduga sebagai SAR mulai dialami sejak masa kanak-kanak. Ulser
SAR yang muncul pertama kali saat kanak-kanak dan adanya riwayat SAR dari orang tua merupakan ciriciri dari SAR yang dipicu oleh faktor etiologi genetik. Dalam literatur disebutkan bahwa SAR yang dialami oleh orang tua akan diturunkan kepada anaknya. Saudara kandung yang mengalami SAR juga merupakan dampak dari SAR yang dialami oleh orang tua yang diturunkan kepada anaknya. ${ }^{8}$ Adanya hubungan antara riwayat SAR dari orang tua yang memicu SAR yang dialami anak-anaknya telah dibuktikan menggunakan Human Leukocyte Antigen (HLA) namun sampai saat ini hal tersebut baru terbukti pada beberapa grup etnik tertentu. ${ }^{10}$

Faktor etiologi stres yang memicu lesi yang diduga sebagai SAR dialami oleh 15 sampel (21,7\%) dalam penelitian ini. Beberapa peneliti telah melaporkan hubungan antara SAR dan keadaan stres yang dialami oleh seseorang. Mahasiswa kedokteran gigi merupakan mahasiswa yang memiliki tingkat stres yang tinggi dibandingkan dengan mahasiswa lainnya. ${ }^{11}$ Dalam sebuah studi pada mahasiswa profesi, SAR sering terjadi pada saat ujian dan saat-saat stres lainnya dalam masa perkuliahan. ${ }^{11}$ Pada musim liburan dihubungkan dengan rendahnya frekuensi dari timbulnya SAR. ${ }^{2,9}$

Faktor etiologi stres merupakan faktor etiologi tertinggi kedua yang memicu terjadinya lesi yang diduga sebagai SAR yang dialami sampel. Hal ini dapat terjadi karena tingginya tingkat stres yang dialami oleh sampel yang merupakan mahasiswa program profesi Dokter Gigi dalam aktivitasnya di klinik dan juga aktivitas sehari-hari. Menurut sebuah penelitian dari Polychronopoulou dan Divaris, hal yang dapat menyebabkan stres pada mahasiswa kedokteran gigi yaitu, kurangnya kepercayaan diri untuk menjadi dokter gigi yang baik di masa depan, administrasi fakultas, beban kerja, perawatan terhadap pasien, tugas dan ujian. $^{11}$ 
Stres dapat disebabkan oleh tuntutan tugas dan pemenuhan target pasien untuk menyelesaikan studinya. Ada juga masalahmasalah pribadi di luar kegiatan di kampus yang menyebabkan stres pada sampel. Faktor etiologi stres yang merupakan faktor etiologi tertinggi kedua yang diduga memicu terjadinya lesi yang diduga sebagai SAR yang dialami sampel juga menyebabkan tingginya angka kejadian dari lesi yang diduga sebagai SAR dalam penelitian ini. ${ }^{11}$

Alergi terhadap beberapa makanan seperti kacang, coklat, kentang goreng, keju, susu,terigu, gandum, kopi, sereal, almond, stroberi dan beberapa makanan dari tomat dihubungkan dengan munculnya SAR pada beberapa pasien. Oleh karena itu lah Hanya 1 sampel (1.1\%) yang harus di rawat dng obat anti alergi selainaplikasi kenalog orabase. pada penelitian ini mengalami lesi yang diduga sebagai SAR. Sampel mengalami gatalgatal pada mukosa mulutnya dan kemudian berkembang menjadi lesi yang diduga sebagai SAR setelah mengonsumsi ikan.

Diperkirakan bahwa sampel mengalami alergi terhadap ikan yang menyebabkan sensasi rasa gatal pada rongga mulut setelah makan ikan sehingga membuat mukosa mulut mengalami luka. Luka ini diduga berkembang menjadi lesi SAR pada rongga mulut, namun belum ditemukan literatur maupun hasil penelitian yang menyebutkan bahwa ikan dapat memicu lesi SAR. ${ }^{10,12,13}$

\section{SIMPULAN}

Angka kejadian Stomatitis apthous rekuren di RSGMP FK Unsrat sebesar 69 orang, yang terdistribusi sebagai berikut: paling banyak terjadi pada perempuan dengan faktor etiologi tersering yaitu trauma, diikuti oleh stres, ketidakseimbangan hormonal, genetik, dan alergi.

\section{SARAN}
1. Pentingnya
masyarakat
untuk mengakses

kesehatan termasuk informasi tentang kesehatan gigi dan mulut yang telah dipublikasikan lewat media internet sehingga masyarakat dapat mengetahui faktor etiologi SAR serta menurunkan angka kejadian SAR dengan cara meminimalisasi faktor etiologinya.

2. Diharapkan dapat dilakukan penelitian lebih lanjut dengan cakupan yang lebih luas dan beragam, sehingga hasilnya dapat digunakan secara umum untuk peningkatan derajat kesehatan gigi dan mulut, khususnya yang berhubungan dengan penyakit mulut.

\section{DAFTAR PUSTAKA}

1. ScullyC, PorterS. Oral mucosal disease: reccurent aphthous Stomatitis. Br J oral maxilofac sur. 2008;46:198-206.

2. Prety L, Mageth KT, Rajkumar K, Karhtik R. Recurent apthous Stomatitis. J oral maxillofac pathol. 2011;15:252-6.

3. McCullough Mj, Abdel-hefeth, Scully C. Recurrent aphthous Stomatitis revisited: clinical features association and new association with infant practices. J oral patol med. 2007:36;216-220.

4. Neville BW, Damm DD, Allen CM, Bouquot JE. Allergies and immunologic diseases. In: Oral and maxillofacial pathology ( ${ }^{\text {rd }}$ ed.). Philadelphia: Elsevier-Saunders. 2009; p. 285-90.

5. Field A, Longman L. Oral ulceration. In: Tyldesley's oral medicine (5th ed.). Oxford: Oxford University Press, 2003; p. 52-8.

6. Nasir A, Muhith A, Ideputri ME. Buku ajar: Metodologi penelitian kesehatan. Yogyakarta: 2011; h. 2278.

7. Greenberg M. Ulcerative, vesicular, and bullous lesions. In: Greenberg, Glick M. Burket's oral medicine diagnosis and treatment $\left(10^{\text {th }}\right.$ ed.). Ontario: BC Decker Inc, 2003; p. 63-5.

8. Scully C. Aphtous ulcers. Medscape. 2013;1-5. Available from URL: http://emedicine.medscape.com/articl 
Jurnal e-GiGi (eG), Volume 3, Nomor 2, Juli-Desember 2015

e/867080-overview

9. Casiglia JM. Aphtous Stomatitis. Medscape.2013;1-7. Available from URL:

http://emedicine.medscape.com/articl e/1075570-overview\#a0104

10.Jurge S. Kuffer R. Scully C .porter SR. Recurrent aphthous Stomatitis. Oral Dis. 2006:12;1-21.

11.Balan U, Gonsalves N, Jose M, Girish KL. Symptomatic changes of oral mucosa during normal hormonal turnover in healthy young menstruating women.

12.Jain A, Bansal R. Stress among medical and dental students: a global issue. JDMS. 2012; 1(5): 5-7.

13. Cawson RA, Odell EW. Diseases of the oral mucosa: non-infective Stomatitis. In: Cawson's essentials of oral pathology and oral medicine (7th ed.). Oxford: ElsevierScience; 2002; p. 192-5. 